УАК 37.104

DOI: 10.37128/2411-4413-2019-9-6

\section{ДОСЛІДЖЕННЯ МАРКЕТИНГУ ЗАКЛАДУ ВИЩОЇ ОСВІТИ ${ }^{\odot}$}

\author{
ЛУЦЯК В.В., \\ доктор економичних наук, \\ кандидат технічних наук, доцент, \\ завідувач кафедри \\ маркетингу та аграрного бізнесу
}

МАЗУР К.В., кандидат економічних наук, доцент, завідувач кафедри аграрного менеджменту

МОСТЕНСЬКА Т.Г., кандидат економічних наук, доцент кафедри аграрного менеджменту

Вінницький національний аграрний університет (м. Вінниця)

Нині заклади вищої освіти повинні відповідати потребам різних суб'єктів підчас надання академічних послуг, пов'язаних з отриманням освіти. Методологія забезпечення даної відповідності представляс собою маркетинг. Шляхом проведення анкетування визначено основні проблемні аспекти в реалізачії стратегічно важливих задач в закладах вищої освіти України. Здійснено кабінетні дослідження та контент аналіз наукових робіт присвячених маркетинговій діяльності зарубіжних університетів. Досліджено інструменти маркетингу та його зміст в університетах. Отримала подальшого розвитку теорія маркетингу в частині формування концепиії маркетингу для закладу вищої освіти. Здійснено обтрунтування та описано ілюстративний приклад використання методологї структурованого маркетингового планування у вищих навчальних закладах. Така структура може бути використана для підтримки розвитку стратегічних програмних можливостей, таких як підтримка нових спеціальностей, кафедр та закладів вищої освіти України, а також для створення нових академічних можливостей для підтримки досліджень і надання якісної освіти.

Ключові слова: маркетинг, стратегія, заклад вищої освіти, концепція, інструменти, план.

Табл.: 1. Рис.: 1. Літ.: 26.

\title{
MARKETING OF A HIGHER EDUCATION INSTITUTION ANALYSIS
}

\author{
LUTSIAK Vitalii, \\ Dr. (economics), PhD (candidate, technics), As. Prof., \\ Head of department of marketing and agrarian business
}

MAZUR Kateryna, PhD '(candidate, economics), As. Prof., Head of Department of Agrarian Management

MOSTENSKA Tetiana, PhD (candidate, economics), As. Prof of Agrarian Management department Vinnytsia National Agrarian University

(Vinnytsia)

Currently, higher education institutions must meet the needs of different actors in the provision of academic services related to the education granting. The methodology for ensuring this correspondence is marketing. By conducting the survey, the main problem areas in the implementation of strategically important tasks in higher education institutions of Ukraine are identified. The desk research and content 
analysis of scientific papers devoted to the marketing activities of foreign universities was conducted. The tools of marketing and its content in universities are investigated. Gained further development of marketing theory in terms of forming a marketing concept for a higher education institution. An illustrative example of the use of the methodology of structured marketing planning in higher education institutions has been substantiated and described. Such a structure can be used to support the development of strategic program capabilities, such as support for new specialties, departments and higher education institutions of Ukraine, as well as for creating new academic opportunities for research support and quality education granting.

Key words: marketing, strategy, higher education institution, concept, tools, plan.

Tabl.: 1. Fig.: 1. Lit.: 26.

\title{
ИССЛЕДОВАНИЕ МАРКЕТИНГА УЧРЕЖДЕНИЯ ВЫСШЕГО ОБРАЗОВАНИЯ
}

\author{
ЛУЦЯК В.В., \\ доктор экономических наук, кандидат технических наук, \\ доцент, заведующий кафедры маркетинга и аграрного бизнеса \\ МАЗУР Е.В., \\ кандидат экономических наук, доцент , \\ заведующий кафедры аграрного менеджмента
}

МОСТЕНСКАЯ Т.Г., кандидат экономических наук, доцент кафедры аграрного менеджмента Винницкий национальный аграрный университет

(2. Винница)

Сейчас учреждения выстего образования должны соответствовать потребностям различных субъектов во время предоставления академических услуг, связанных с получением высшего образования. Методология обеспечения данного соответствия представляет собой маркетинг. Путем проведения анкетирования определены основные проблемные аспекты в реализации стратегически важных задач в учреждениях высшего образования Украины. Осуществлены кабинетные исследования и контент-анализ научных работ посвященных маркетинговой деятельности зарубежных университетов. Исследованы инструменты маркетинга и его содержание в университетах. Получила дальнейтее развитие теория маркетинга в части формирования концепции маркетинга для учреждения выстего образования. Осуществвлено обоснование и описан иллюстративный пример использования методологии структурного маркетингового планирования в университете. Такая структура может быть использована для поддержки развития стратегических программных возможностей, таких как поддержка новых спечиальностей, кафедр и учреждений высшего образования Украины, а также для создания новых академических возможностей для поддержки исследований и предоставления качественного образования.

Ключевые слова: маркетинг, стратегия, учреждение высшего образования, концепция, инструменты, план.

Табл.: 1. Рис.: 1. Лит.: 26.

Постановка проблеми. Університети і дослідницькі установи є великими і складними організаціями, що повинні бути гнучкими і адаптивними у відповідності до постійних змін [13, с. 201]. Нині університети повинні відповідати потребам різних суб'єктів підчас надання академічних послуг, пов'язаних з формуванням освіти, а у випадку науково-дослідних організацій, також передбачається і проведення досліджень. Діяльність в сфері обміну знаннями призводить до конвертації знань та результатів досліджень у комерційні або соціальні вигоди для більш широкого кола суб'єктів [18, с. 28]. В даному контексті університети розглядаються як такі, що відіграють стратегічну роль шляхом стимулювання інновацій та економічного зростання через трансфер технологій i, як наслідок, комерційне використання інтелектуальної власності [9, с. 730].

В теперішніх умовах господарювання, що характеризуються змінами влади, реформами в усіх сферах діяльності держави, університети стикаються з низкою відповідних проблем. Зростає тиск в сфері бюджетування, особливо на фінансування, що забезпечується державними джерелами. Конкуренція між університетами зростає на декількох рівнях: змагання за кращих студентів і співробітників, за фінансування досліджень [25, с. 473].

У цьому контексті університети повинні забезпечувати собі можливість адаптування до нових перспектив і реагувати на стратегічні пріоритети ефективним і економічним чином. Виникнення потенційно масштабних перспектив породжує потребу у забезпеченні маркетингової підтримки 
діяльності закладів вищої освіти [11, с. 69]. Маркетинг та ринкові результати завжди мають місце поруч 3 академічною діяльністю, $є$ передумовами фінансової підтримки і розглядаються як невід'ємна частина господарювання закладу вищої освіти органом фінансування, що може бути представлений урядовою організацією, промисловим підприємством, благодійним фондом, або навіть самим університетом.

Розробка маркетингової стратегії для нової ініціативи вимагає відповідних компетенцій для залучення необхідного фінансування. Незважаючи на те, що підприємства мають досвід у маркетинговій діяльності, в непрофільній і академічній галузях історично існує менша потреба в таких компетенціях і здібностях. Проте, все частіше університети та дослідницькі організації переймають управлінські практики, отримані з корпоративного середовища [14, с. 69].

Аналіз останніх досліджень і публікацій. Ключовою функцією управління, яку керівники закладів вищої освіти не повинні ігнорувати, щоб вижити в конкурентному середовищі сьогодні, $\epsilon$ маркетинг. Проте у вітчизняній літературі не приділяється достатньої уваги ринку чи маркетингу в контексті вивчення їхнього впливу на інституцію вищої школи, особливо в Україні. Натомість, у зарубіжних наукових роботах існує значний інтерес до маркетингу у вищій освіті [3, с. 129].

Фоскет H. (Foskett N.) [5, c. 248] зазначив, що маркетинг розглядається як цілісний процес управління. Це управлінська філософія, що відбиває ідеальні відносини між закладом вищої освіти та суспільством [15, с. 298]. Котлер і Фокс (Kotler \& Fox) [11, с. 89] визначили маркетинг освіти як аналіз, планування, впровадження та контроль ретельно сформульованої програми, що полягає у добровільному обміні цінностями на цільовому ринку для досягнення організаційних цілей. Концепція маркетингу в освіті не нова. Маркетинг у сфері освіти впроваджувався в багатьох західних країнах протягом 1980-х і 1990-х років [16, с. 208].

Існує безліч інтерпретацій маркетингу серед ректорів у вищих навчальних закладах, де термінологія є новою для більшості і чужа для багатьох [5, 246 с.]. Визначення маркетингу були сплутані $з$ продажем з акцентом на рекламу, рекламну діяльність, зв'язки з громадськістю, рекламні повідомлення, маніпуляції з інформацією. Котлер Ф. [11, с. 59] підкреслив, що маркетинг - це не просто продаж. Маркетинг в освіті має інші цілі, ніж просто забезпечити набір студентів. Наприклад, в сучасних умовах відтоку контингенту студентів за кордон виявляється недостатнім спрямування зусиль лише на набір, але більше зусиль необхідно спрямовувати на управління якістю надання освіти та реагування на потреби партнерів, зацікавлених сторін та спільноти [12, с. 127]. Фоскет також припускає, що маркетинг стосується задоволення організаційних потреб для виживання та успіху [5, с. 242].

Між тим, в галузі освіти існують як позитивні так і негативні уявлення про маркетинг. Деякі керівники університетів в Україні та у дослідженні [10, с. 82] вважають, що маркетинг як антикризовий менеджмент забезпечує виживання університету, на відміну від того, щоб бути спрямованим на задоволення потреб своїх клієнтів. Два дослідження, проведені в Англії [5, с. 250] та [6, с. 18], показали, що керівники та науково-педагогічний персонал стверджують, що освіта не може пропонуватись таким самим чином як бізнес-послуга чи продукт. В дослідженні [15, с. 299] ідеться про важливість маркетингу як управлінської функції для виживання та успіху закладу освіти за умови, що він транслює лише реальні та чесні інформаційні та рекламні повідомлення [9, с. 741].

При цьому, розвиток цифрової техніки і технологій в сфері комунікації надає університетам можливості розширення масштабів наукової діяльності і підвищення рівня якості викладання [24, c. 90]. Додаткові освітні канали, що можуть мати форму масових відкритих он-лайн курсів, розробляються і пропонуються все більшою кількістю університетів в світі [4, с. 5]. Нові можливості виникають у відповідь на вирішення питань забезпечення фінансування та можуть мати форму мультидисциплінарних дослідницьких центрів [17, с. 107], або створення нових науководослідних установ, що об'єднують академічні організаційні утворення для зосередження на конкретних промислових запитах або суспільних потребах [26].

Метою статті $є$ формування підходу сприяння розвитку стратегічних академічних ініціатив в закладах вищої освіти шляхом використання структурованої методології маркетингового планування.

Виклад основних результатів дослідження. Перша частина даного дослідження базується на виконанні польового дослідження. Було розроблено анкету з мето дізнатись точку зору респондентів щодо узагальнення проблемних аспектів розробки та реалізації маркетингових стратегій в університетах. Анкета містить ряд близьких непрямих питань, що базуються на впливі зовнішнього та внутрішнього організаційного середовища на досягнення позитивних результатів 
при реалізації маркетингової стратегії. Опитування проводилося в режимі он-лайн через сайти соціальних мереж, і було зібрано відповіді 50 респондентів. Інструмент (анкета) було розміщено у документах Google, а посилання було надіслано користувачам для заповнення інструменту через різні сайти соціальних мереж, таких як Facebook, Twitter, LinkedIn, Instagram, Snapchat, WhatsApp.

Респондентам також було запропоновано розмістити посилання на анкету зі свого профілю. Таким чином, використовувана методика формування вибірки була не імовірнісною показовою вибіркою. Для тестування гіпотези ми використовували регресійний аналіз. Міра узгодженості думок експертів була перевірена розрахунком коефіцієнта конкордації Кенделла та коефіцієнта кореляції Пірсона.

Результати даного дослідження дозволили встановити, що має місце вірогідність виникнення певних проблем, особливо для стратегічних академічних планів (табл. 1).

Таблиия 1

Узагальнений перелік основних проблемних аспектів щодо реалізації стратегічних академічних маркетингових планів

\begin{tabular}{|c|}
\hline маркетингових планів \\
\hline 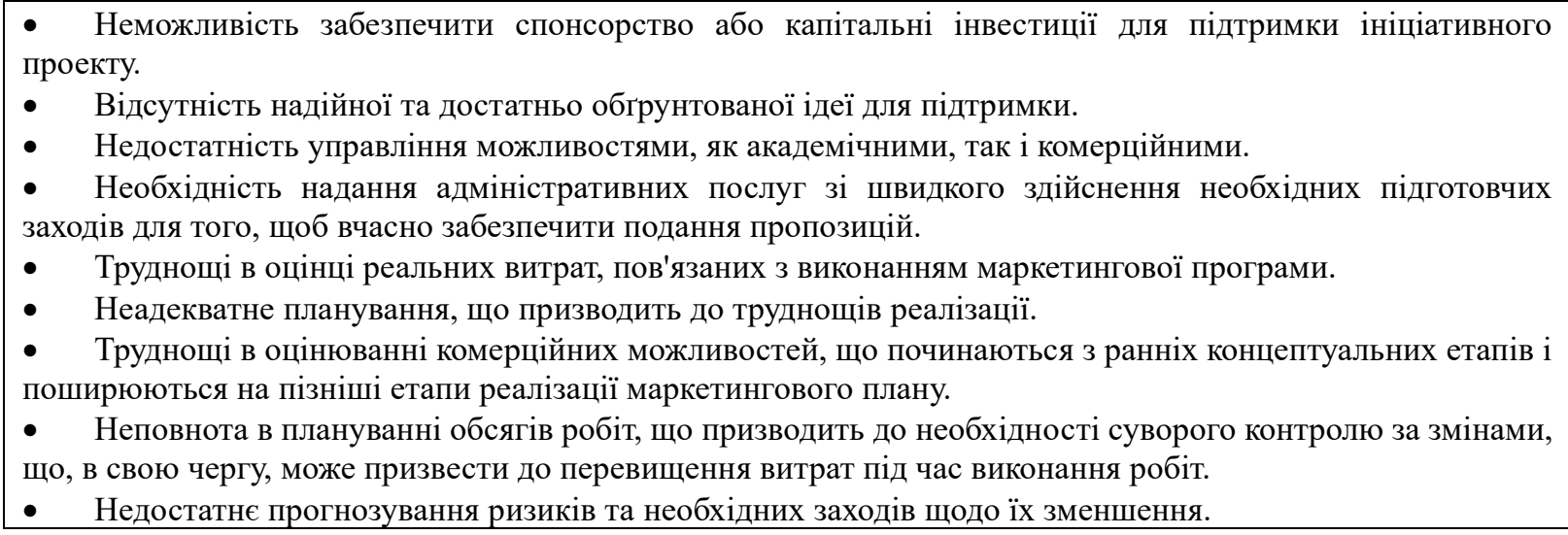 \\
\hline
\end{tabular}

Джерело: сформовано автором на основі власних даних та даних [19, 26 с.].

Перспективним шляхом подолання проблем та створення нових можливостей є використання методології маркетингу для підтримки нових спеціальностей, кафедр та закладів вищої освіти України [11, с. 9].

Маркетингова стратегія університету спрямовується на досягнення загальних стратегічних цілей, що містяться в стратегії університету. Цілі маркетингової стратегії університетів можна визначити таким чином [3, с. 138]:

1. Залучення оптимальної кількості студентів;

2. Постійне вдосконалення навчальних планів;

3. Отримання коштів для наукових досліджень;

4. Розробка матеріально-педагогічних та дослідницьких засобів;

5. Співпраця з економічними та соціальними інституціями;

6. Залучення науково-педагогічних кадрів.

Для реалізації маркетингових цілей університету необхідними $є$ відповідні маркетингові інструменти [11, с. 58]. Попри відомість усіх можливих інструментів, що можуть бути використані вищими закладами освіти, можна припустити, що не усі з них діють однаково ефективно. На підтвердження даної гіпотези, у дослідженні [12, с. 129] було здійснено опитування 131 університету у Великобританії. Важливо відмітити, що 75\% університетів мають відділ маркетингу iз середнім розміром штату 10 осіб. В переважній більшості університетів розробляється стратегічний маркетинговий план на 5 років, короткостроковий маркетинговий план на рік та більше 50\% університетів мають маркетингові плани для усіх власних відділів. Результати дослідження доводять, що найбільш ефективними маркетинговими інструментами є наступні:

- контактування з шкільним радником із забезпечення кар'єрного розвитку учнів;

- відвідування шкіл рекрутерами;

- проведення кар'єрних ярмарок;

- отримання акредитації від професійних організацій;

- пропонування широкого кола курсів; 
- географічне розташування;

- проведення днів відкритих дверей в університетському містечку;

- тісні галузеві зв'язки;

- зображення, що транслюються громадськості;

- висока якість викладання;

- репутація науково-педагогічного персоналу;

- академічна репутація;

- результати досліджень.

Більшість 3 даних інструментів 3 перемінним успіхом використовуються в усіх університетах України, однак, вітчизняне інституційне середовище обмежує дане коло інструментів, виключаючи з нього радника з кар'єрного розвитку у школах, роль якого може виконувати класний керівник або представник адміністрації школи. Також нам не відомо про існування у вітчизняному професійному просторі професійних організацій, що можуть чинити відчутний вплив на суб'єктів під час надання академічних послуг з отримання освіти.

При цьому, в [12, с. 131] також представлені інструменти, що мають відносно низьку ефективність i, скоріше за все, доповнюють основні інструменти маркетингу для забезпечення ефекту синергії [23, с. 64] при їх використанні у певних комбінаціях [20, с. 19]. Такими маркетинговими інструментами є:

-пропонування більш низьких цін на навчання ніж конкуренти;

- доступність стипендій;

-відвідування посольств та вищих комісій.

Інтеграція маркетингових інструментів закладу вищої освіти може бути представлена у вигляді воронки в якій зосереджуються інструменти, що пов'язані між собою. При цьому, як тільки досягається достатній рівень узгодженості у використанні пов'язаних інструментів маркетингу досягається ефект синергії [20, с. 36]. В подальших дослідженнях слід здійснювати аналіз рівня інтеграції пов'язаних маркетингових інструментів з урахуванням особливостей закладу вищої освіти та встановлювати ефективні для конкретного середовища воронки з метою отримання ефекту синергії.

Важливим результатом прикладних досліджень також є оцінка сприйняття ролі маркетингу в різних університетах [12, с. 132]. Подібно до результатів, що отримані стосовно ефективності маркетингових інструментів, значення маркетингу оцінено експертами по-різному в залежності від аспекту. Так, більшість експертів вважають, що маркетинг в університеті представляє собою:

- дослідження причин відмови студентів від навчання;

- розробка маркетингових планів;

- маркетинг здійснюють декани та голови відділів;

- аналіз інститутів-конкурентів;

-якість задоволеності студентів;

-завідувачі кафедр - вчені-дослідники;

-попит на освітні послуги перевищує пропозицію.

Відповідно, маркетинг в університетах найменше ототожнюється з наступними тезами:

- маркетинг означає рекламні звернення;

- вибір університету та географічного розташування;

- маркетинг є абстрактною теорією;

- маркетингове планування забезпечує незначні переваги;

- роль маркетингу полягає у приваблюванні нових студентів;

- нові університети становлять незначну загрозу;

- потреби студентів $є$ вторинними;

- дослідження перспективних вимог.

Виходячи 3 наведених результатів, можна сформулювати концептуальне розуміння маркетингу в університетах. На нашу думку, маркетинг в університетах полягає у розробці маркетингових планів деканами факультетів та головами відділів з урахуванням перспективних напрямів наукових досліджень кафедр університету, повинні містити аналіз діяльності інститутівконкурентів та можливі напрями співпраці з ними, дослідження якості задоволеності студентів навчанням та перебуванням у студмістечку 3 метою запобіганню виникнення причин відмови 


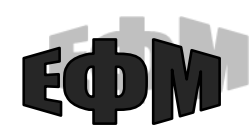

http://efm.vsau.org/

студентів від навчання та забезпечення попиту на освітні послуги університету у кількості, що перевищує ліцензовані обсяги набору абітурієнтів. При цьому, слід дотримуватись низки принципів із забезпечення якості маркетингової діяльності:

1. Маркетинг повинен охоплювати усі елементи комплексу маркетингу-мікс для закладів вищої освіти (продукт, місце, ціну, просування, кадри, процес, докази, фізичні стимули) [8, 1 с. 57-160].

2. Цільовий ринок не має просторових меж.

3. Конкретизація маркетингових задач.

4. Орієнтація на забезпечення відчутного ефекту.

5. Дослідження ринку в трьох часових інтервалах - історія, сьогодення, прогноз - із орієнтацією на задоволення потреб студентів та аналізом діяльності конкурентів.

6. Встановлення співпраці з університетами-конкурентами.

7. Міжфункціональна координація.

Дослідження [12, с. 133] містить суттєвий висновок стосовно вибору маркетингової стратегії університетами в залежності від їх умовного віку. Так, старі університети діють на ринку таким чином, як їм здається, вони можуть діяти найкраще, а саме здійснюють дослідження та провадять навчання у аудиторіях. Іншими словами, вони намагаються оптимізувати навчальний процес з того моменту як студенти потрапляють в аудиторії. Натомість, новостворені університети фокусують зусилля на сприйнятті абітурієнтів місця майбутнього навчання. Нові університети не мають традицій у викладанні та здійсненні досліджень та практикують більш агресивний підхід 3 досягнення абітурієнтів у процесі прийняття рішення. Для новостворених університетів така стратегія має сенс оскільки рішення про вибір місця майбутнього навчання абітурієнтом зазвичай $\epsilon$ дуже складним і вимагає значного залучення абітурієнта до співставлення варіантів та встановлення між ними значущої різниці [2, с. 36]. Задача суб'єкта прийняття рішення зводиться до зменшення ризику. Тому, чим більше деталей про університети абітурієнт дізнається на ранніх стадіях процесу прийняття рішення, тим більше переваг це створює для нового університету.

Шляхом простої аналогії можна сформулювати маркетингові задачі для новоствореної кафедри в складі старого університету - поєднання обох підходів. Це може виявитись доволі складною організаційною роботою, проте, в сучасних інституційних умовах та в умовах посилення конкурентної боротьби - це є єдиним шляхом, що може привести до успіху.

Дослідження [1, с. 3] підтверджує той факт, що не зважаючи на значні зусилля в роботі із переконання абітурієнтів вступати в університети України на ті чи інші спеціальності, все ж тут виникає значна кількість серйозних перешкод. Слід відмітити, що в країнах із педагогічною традицією Великобританії із абітурієнтами працюють радники з кар'єри, а їх значна роль у виборі подальшого професійного спрямування учнями шкіл підтверджується в багатьох наукових роботах. Однак, при цьому, також відмічається і те, що в багатьох випадках таким радникам не вистачає спеціальних знань про конкретні професії, що також має значний вплив на вибір абітурієнтів [22, с. 116].

У відповідь на дану проблему [7, с. 28] в університеті Карнегі Меллон (Carnegie Mellon University) були розроблені презентації, що давали відповідь на два головних питання стосовно майбутньої професії абітурієнтам. Їх безособова форма може бути представлена як «Хто може бути ... ?» та «Що б Ви могли зробити як би мали науковий ступінь за спеціальністю ... ?». Друга ініціатива - щотижневі майстер-класи. В такий спосіб досягалось формування нового іміджу спеціалістів та їх вмінь. Принциповими компонентами таких спроб були такі [21, с. 56]:

1) змінити послідовність проведення профорієнтації, щоб зробити іiі доступною для більш широкої аудиторії;

2) забезпечити рольові моделі (приклади) для абітурієнтів;

3) запровадити спеціальні програми для абітурієнтів, які піддаються більшому ризику виходу 3 цільового напряму підготовки;

4) створити програму для залучення студентів до факультетських досліджень.

Виходячи з проведеного аналізу сутності маркетингу закладів вищої освіти, обгрунтування необхідності тактичного планування маркетингової діяльності та визначення сукупності ефективних маркетингових інструментів, ми пропонуємо план маркетингових заходів для розвитку нових спеціальностей кафедр закладів вищої освіти України.

1. Формування маркетингового комітету. Основною задачею комітету є збільшити помітність кафедри та створити інтерес і зацікавленість серед абітурієнтів щодо пропонованих спеціальностей. Не менш важливою задачею $є$ забезпечення постійно діючої кампанії 3 просування нової спеціальності в закладах середньої освіти та профтехосвіти. 
2. Розробка плану маркетингових заходів із просування нової спеціальності.

Загальний вигляд маркетингової стратегії представлено на рисунку 1.

Демонстрація презентацій. Даний вид діяльності повинен здійснюватись на початку навчання учнів загальноосвітніх шкіл у випускових класах. В цей період здійснюється вибір дисциплін за якими учні готуватимуться до ЗНО. Презентації в цей період допоможуть випускникам шкіл обрати собі консультанта з майбутньої професії. Головна мета заходів із демонстрації презентацій в даний період створити міцний зв'язок між університетом та учнями, що виявляють зацікавленість у пропонованій спеціальності. Тут слід підсилити зацікавленість у працевлаштуванні за пропонованою спеціальністю. План заходів із демонстрації презентацій може мати наступний вигляд:

1. Підготовка та демонстрація презентацій двома блоками протягом першої-другої чверті навчання та третьої-четвертої чверті навчання випускників у школах.

2. Проведення опитувань до презентації та після презентації.

3. Організація зустрічей з консультантами.

4. Відеоадаптація презентацій для повторного їх використання консультантами.

5. Розробка матеріалів у відповідності до результатів опитувань для їх використання під час проведення університетських заходів (днів відкритих дверей, дня університету тощо).

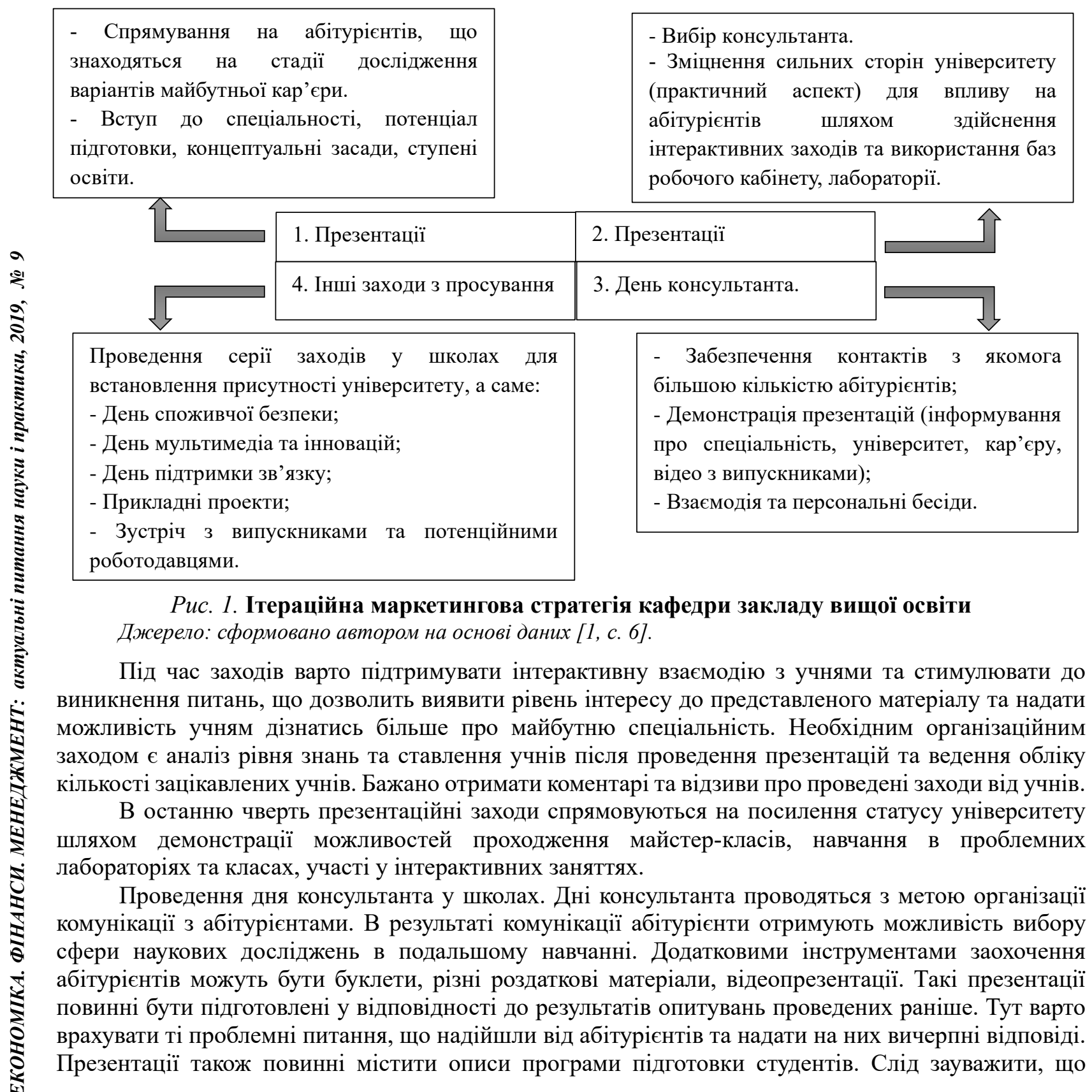


програми підготовки, представлені у дослідженні $[1,1-15$ с.] мали три різновиди і включали спільні програми поглибленої співпраці 3 бізнесом, поглибленого навчання в сфері педагогіки та поглиблене вивчення сучасних професійних інструментів. Під час даного заходу варто організувати зустрічі з випускниками та спеціалістами в сфері пропонованої спеціальності. Перевагою при формуванні позитивного ставлення абітурієнтів до майбутньої спеціальності є роз'яснення ролі та способів використання набутих професійних компетенцій в роботі спеціаліста.

Виставкові тижні. Для підвищення помітності університету можуть проводитись заходи із демонстрації агітаційних програм протягом декількох днів для широкого кола абітурієнтів на базі університету. Метою таких заходів є створення позитивного іміджу студентів пропонованої спеціальності шляхом демонстрації результатів роботи студентів під час навчання в університеті. Такі заходи також дозволяють студентам інших спеціальностей ознайомитись 3 роботами своїх сокурсників та дізнатись про сильні сторони спеціалістів інших спеціальностей. Формат заходів може бути наступним:

1. Облаштування демонстраційних майданчиків, що діятимуть протягом тривалого періоду часу в дні проведення виставки.

2. Демонстраційні майданчики можуть використовуватись студентами для презентації їх робіт, що пов'язані із тематичними напрямами їх навчання.

3. Фокус на візуалізації та інтерактивності.

4. Можливим $є$ інсталяція демонстраційних моделей для привернення уваги.

Для ефективної реалізації маркетингової стратегії закладу вищої освіти маркетинговий комітет повинен регулярно звітувати перед керівництвом. Робоче навантаження для реалізації заходів повинне бути розподіленим між усіма науково-педагогічними кадрами, оскільки інтересом кожного $є$ забезпечення успіху. Такий внесок у маркетингову стратегію закладу вищої освіти може бути запланований згідно діючих положень про нормування робочого часу науково-педагогічних працівників.

Висновки. В даній роботі ми визначили основні цілі маркетингової стратегії університетів; встановили перелік відповідних маркетингових інструментів; сформулювали сутнісну характеристику маркетингу в університетах, що повинна бути підкріплена дотриманням принципів із забезпечення якості маркетингової діяльності; запропоновано план маркетингових заходів для розвитку нових спеціальностей кафедр закладів вищої освіти України.

Складність маркетингової стратегії закладів вищої освіти та їх відділів обумовлює необхідність наявності у спеціалістів маркетингового комітету ряду важливих компетенцій. Такий набір компетенцій повинен бути детально досліджений та сформований у відповідності до умов середовища та особливостей пропонованих абітурієнтам спеціальностей. В наших подальших дослідженнях ми плануємо висвітлити власні результати щодо формування набору необхідних компетенцій при плануванні маркетингової стратегії нових спеціальностей університету.

\section{Список використаних джерел}

1. Abu Talib M., Ormandjieva O. An Innovative Marketing Strategy to Promote our College of IT: Zayed University Case Study. Issues in Informing Science and Information Technology. 2012. Volume 7. P. $1-15$.

2. Assael H. Consumer Behavior and Marketing Action. Boston : Kent Publishing Company, MA, $1981.718 \mathrm{p}$.

3. Białon L. Creating marketing strategies for higher education institutions. MINIB. 2015. Vol. 18, Issue 4. P. 129-146.

4. Daniel J. Making sense of MOOCs: Musings in a maze of myth, paradox and possibility. Journal of Interactive Media in Education. 2012. Vol. (3). P. 1-20.

5. Foskett N. Marketing. The Principles and Practice of Educational Management. In Bush T. and Bell L. (Eds). London : Paul Chapman. 2002. P. 241-257.

6. Foskett N., Hemsley-Brown J. Choosing futures: Young people's decision making in education, training and career markets. London: Routledge-Falmer. 2001. 244 p.

7. Frieze C., Treat E. Diversifying the images of computer science: Carnegie Mellon students take on the challenge! Women in Engineering Programs and Advocates Network (WEPAN) Conference. USA. 2006.

8. Hamid S.A., Musa K. Understanding the relevance of marketing for Malaysian schools. Management Research Journal. 2014. Vol. 3. P. 155-163.

9. Hughes A., Kitson M. Pathways to impact and the strategic role of universities: new evidence on the breadth and depth of university knowledge exchange in the UK and the factors constraining its development. Cambridge Journal of Economics. 2012. 36(3). P. 723-750. 


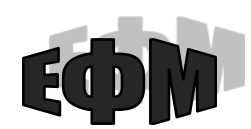

http://efm.vsau.org/

10.James C., Phillips P. The practice of educational marketing in schools. Educational Management and Administration. 1995. Vol. 23(2). P. 75-88.

11.Kotler P., Fox K. A. Strategic marketing for educational institutions. New York : PrenticeHall. 1995. $484 \mathrm{p}$.

12.Naude P., Ivy J. The marketing strategies of universities in the United Kingdom. International Journal of Educational Management. 2015. Vol. 13/3. P. 126-134.

13. Navarro J. R., Gallardo, F. O. A model of strategic change: Universities and dynamic capabilities. Higher Education Policy. 2003. Vol. 16(2). P. 199-212.

14.Nickson A. A qualitative case study exploring the nature of New Managerialism in UK higher education and its impact on individual academics' experience of doing research. Journal of Research Administration. 2014. Vol. 45(1). 47-80.

15. Oplatka I., Hemsley-Brown J. The incorporation of market orientation in the school culture: An essential aspect of school marketing. International Journal of Educational Management. 2007. Vol. 21(4). P. 292-305.

16. Oplatka I., Hemsley-Brown J., Foskett N. H. The voice of teachers in marketing their school: Personal perspectives in competitive environments. School Leadership and Management. 2002. Vol. 22(2). P. 177-196.

17.Philbin S. P. An investigation of the development and management of university research institutes. Journal of Research Administration. 2011. Vol. 42(1). P. 103-122.

18.Philbin S. P. Exploring the challenges and opportunities for higher education institutions: Work domain analysis and development of strategic options. PICMET '15: Management of the Technology Age, Portland (OR), USA, IEEE. 2015.

19.Philbin S. P., Mallo C. A. Business Planning Methodology to Support the Development of Strategic Academic Programmes. The Journal of Research Administration. 2016. Vol. (47)1. P. 25-39.

20. Pickett S., Vinten G. The internal auditing handbook. Chichester : John Wiley \& Sons Ltd, 2000. 1092 p.

21.Roberts E. S., Kassianidou M., Irani L. Encouraging women in computer science. Stanford : CA. ACM SIGCSE Bulletin - Women and Computing. 2002. Volume 34, Issue 2. P. 84-88.

22. Saunders M. L., Hunsinger D. S. Encouraging students to choose a computer-related major: The influence of guidance counselors. Boone, USA: Information Systems Education Conference. 2008.

23.Schüller D., Rašticová M. Marketing Communications Mix of Universities - Communication With Students in an Increasing Competitive University Environment. Journal of Competitiveness. 2011. Issue 3. P. 58-71.

24. Selwyn N. The use of computer technology in university teaching and learning: a critical perspective. Journal of Computer Assisted Learning. 2007. Vol. 23(2). P. 83-94.

25.Ter Bogt H. J., Scapens R. W. Performance management in universities: Effects of the transition to more quantitative measurement systems. European Accounting Review. 2012. Vol. 21(3). P. 451-497.

26.НHВК "Всеукрайнський науково-навчальний консориіум" : веб-сайт. URL: https://vsau.org/pro-universitet/nnvk-vseukraiinskij-naukovo-navchalnij-konsorczium_(дата звернення 29.06.2019).

\section{References}

1. Abu Talib, M., Ormandjieva, O. (2012).An Innovative Marketing Strategy to Promote our College of IT: Zayed University Case Study. Issues in Informing Science and Information Technology, Volume 7, 1-15.

2. Assael, H. (1981). Consumer Behavior and Marketing Action. Boston: Kent Publishing Company.

3. Białoń, L. (2015). Creating marketing strategies for higher education institutions. MINIB, Vol. 18 , Issue 4, 129-146.

4. Daniel, J. (2012). Making sense of MOOCs: Musings in a maze of myth, paradox and possibility. Journal of Interactive Media in Education, 2012(3), 1-20.

5. Foskett, N. (2002). Marketing. In Bush, T. and Bell, L. (Eds), The Principles and Practice of Educational Management. Paul Chapman, London, 241-257.

6. Foskett, N., \& Hemsley-Brown, J. (2001). Choosing futures: Young people's decision making in education, training and career markets. London: Routledge-Falmer.

7. Frieze, C., \& Treat, E. (2006). Diversifying the images of computer science: Carnegie Mellon students take on the challenge! USA: Proceedings from Women in Engineering Programs and Advocates Network (WEPAN) Conference.

8. Hamid, S.A., Musa, K. (2014). Understanding the relevance of marketing for Malaysian schools. Management Research Journal, Vol. 3, 155-163. 
9. Hughes, A., \& Kitson, M. (2012). Pathways to impact and the strategic role of universities: new evidence on the breadth and depth of university knowledge exchange in the UK and the factors constraining its development. Cambridge Journal of Economics, 36(3), 723-750.

10.James, C., \& Phillips, P. (1995). The practice of educational marketing in schools. Educational Management and Administration, 23(2), 75-88.

11.Kotler, P. \& Fox, K.A. (1995). Strategic marketing for educational institutions. New York: PrenticeHall.

12.Naude, P., Ivy, J. (2015). The marketing strategies of universities in the United Kingdom. International Journal of Educational Management, 13/3, 126-134.

13.Navarro, J. R., \& Gallardo, F. O. (2003). A model of strategic change: Universities and dynamic capabilities. Higher Education Policy, 16(2), 199-212.

14.Nickson, A. (2014). A qualitative case study exploring the nature of New Managerialism in UK higher education and its impact on individual academics' experience of doing research. Journal of Research Administration, 45(1), 47-80.

15.Oplatka, I., \& Hemsley-Brown, J. (2007). The incorporation of market orientation in the school culture: An essential aspect of school marketing. International Journal of Educational Management, 21(4), 292-305.

16. Oplatka, I., Hemsley-Brown, J., \& Foskett, N.H. (2002). The voice of teachers in marketing their school: Personal perspectives in competitive environments. School Leadership and Management, 22(2), 177-196.

17.Philbin, S. P. (2011). An investigation of the development and management of university research institutes. Journal of Research Administration, 42(1), 103-122.

18.Philbin, S. P. (2015). Exploring the challenges and opportunities for higher education institutions: Work domain analysis and development of strategic options. Proceedings from PICMET '15: Management of the Technology Age, Portland (OR), USA, IEEE.

19.Philbin, S. P., Mallo, C. A. (2016). Business Planning Methodology to Support the Development of Strategic Academic Programmes. The Journal of Research Administration, (47)1. 25-39.

20. Pickett, S., \& Vinten, G. (2000). The internal auditing handbook. Chichester: John Wiley \& Sons Ltd.

21.Roberts, E. S., Kassianidou, M., \& Irani, L. (2002). Encouraging women in computer science. Stanford, CA. ACM SIGCSE Bulletin - Women and Computing, Volume 34, Issue 2. 84-88.

22.Saunders, M. L., \& Hunsinger, D. S. (2008). Encouraging students to choose a computer-related major: The influence of guidance counselors. Proceedings from Boone, USA: Information Systems Education Conference.

23.Schüller, D., Rašticová, M. (2011). Marketing Communications Mix of Universities Communication With Students in an Increasing Competitive University Environment. Journal of Competitiveness, Issue 3, 58-71.

24. Selwyn, N. (2007). The use of computer technology in university teaching and learning: a critical perspective. Journal of Computer Assisted Learning, 23(2), 83-94.

25.Ter Bogt, H. J., \& Scapens, R. W. (2012). Performance management in universities: Effects of the transition to more quantitative measurement systems. European Accounting Review, 21(3), 451-497.

26.BHAУ. (2019). NNVK "Vseukrayinskyj naukovo-navchalnyj konsorcium". [All-Ukrainian Scientific-Training Consortium "All-Ukrainian Scientific Consortium"]. Retrieved from: https://vsau.org/pro-universitet/nnvk-vseukraiinskij-naukovo-navchalnij-konsorczium [in Ukrainian].

\section{Інформація про авторів}

ЛУЦЯК Віталій Васильович - д.е.н., к.т.н., доц., завідувач кафедри маркетингу та аграрного бізнесу, Вінницький національний аграрний університет (21021, м. Вінниця, вул. Келецька, 94, 69, LutsiakVV@gmail.com).

МАЗУР Катерина Василівна - к.е.н., доц., завідувач кафедри аграрного менеджменту, Вінницький національний аграрний університет (21008, м. Вінниця, вул. Пирогова, 3, kv_mazur@ukr.net).

МОСТЕНСЬКА Тетяна Геннадіївна - к.е.н., доцент кафедри аграрного менеджменту, Вінницький національний аграрний університет (21008, м. Вінниця, вул. Пирогова, 3, mostik_t@ukr.net).

LUTSIAK Viyalii Vasylovitch - Dr. (economics), PhD (candidate, technics), As. Prof., Head of department of marketing and agrarian business. Vinnytsia National Agrarian University (21021, Vinnitsia, Keletska st., 94,69, LutsiakVV@gmail.com). 
MAZUR Kateryna Vasylivna - PhD (candidate, economics), As. Prof., Head of The Department of Agrarian Management, Vinnytsia National Agrarian University (21008, Vinnitsia, Pirohova st., 3, kv_mazur@ukr.net).

MOSTENSKA Tetiana Gennadiyivna - PhD (candidate, economics), As. Prof of Agrarian Management Department, Vinnytsia National Agrarian University (21008, Vinnitsia, Pirohova st., 3, mostik_t@ukr.net).

ЛУЦЯК Виталий Васильевич - д.э.н., к.т.н., доц., заведующий кафедры маркетинга и аграрного бизнеса, Винницкий национальный аграрный университет (21021, г. Винница, ул. Келецкая, 94, 69, LutsiakVV@gmail.com).

МАЗУР Екатерина Васильевна - к.э.н., доц. заведующая кафедрой аграрного менеджмента, Винницкий национальный аграрный университет (21008, г. Винница, ул. Пирогова, 3, kv_mazur@ukr.net).

МОСТЕНСКАЯ Татьяна Геннадиевна - к.э.н., доцент кафедры аграрного менеджмента, Винницкий национальный аграрный университет, Винницкий национальный аграрный университет (21008, г. Винница, ул. Пирогова, 3, mostik_t@ukr.net). MOSTENSKA Tetiana Gennadiyivna - PhD (candidate, economics), As. Prof of Agrarian Management Department, Vinnytsia National Agrarian University (21008, Vinnitsia, Pirohova st., 3, mostik t @ $@ u k r . n e t)$.

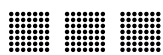

УАК 658.:664.1

DOI: 10.37128/2411-4413-2019-9-7

\section{КОНЦЕПТУАЛЬНІ ПІДХОДИ ДО ФОРМУВАННЯ МАРКЕТИНГОВОЇ СТРАТЕГIÏ ПІДПРИЕМСТВ БУРЯКОЦУКРОВОГО ПІДКОМПЛЕКСУ $\odot$}

КРАСНЯК О.П., кандидат економічних наук, доцент кафедри маркетингу та аграрного бізнесу,

AMOHC C.E., кандидат сільськогосподарських наук, доцент кафедри маркетингу та аграрного бізнесу,

Вінницький національний аграрний університет (м. Вінниця)

У статті розглянуто концептуальні засади розробки та реалізаиії маркетингової стратегії підприємств бурякоиукрового підкомплексу; охарактеризовано етапи формування стратегї; розкрито комплекс економіко-організаційних проблем реалізації стратегічного маркетингового підходу на ринку сільськогосподарської продукиії.

Встановлено, ще вітчизняне иукропереробне виробництво залишається одним із стратегічно важливих напрямів агропромислового комплексу та на сьогодні зберігає перспективи стабілізаиії попри певні проблемні аспекти у розвитку підприємств иукропереробної галузі в иілому.

Представлено основні аспекти формування маркетингової стратегї переробних підприємств; описано зв'язок між фазами розвитку продовольчого маркетингу та рівнем застосування продовольчої маркетингової стратегії. На основі иьього дослідження розроблено комплекс концептуальних підходів маркетингової стратегії підприємства, застосування якого має сприяти забезпеченню систематизованого підходу до ї̈ планування, реалізаиії та контролю.

Результати здійснених досліджень показують, щзо товарна політика підприємств иукробурякового підкомплексу Украӥни повинна бути зорієнтована на постійне покращення якості продукиї як одного із пріоритетних напрямів діяльності иукрового заводу, щьо забезпечує його конкурентні переваги на аграрному ринку. Асортиментна складова передбачає комплексне застосування диверсифікації товарного виробництва иляхом удосконалення наявного асортименту та переробки побічної продукиії. 